\title{
Experimental Investigation of Treatment of Domestic Wastewater Using Multi Soil Layering (MSL) System
}

\author{
Vaishnavi Vyankatesh Deshpande ${ }^{1 *}$, Akshay Rajan Thorvat ${ }^{1}$ \\ ${ }^{1}$ Department of Environmental Engineering, Kolhapur Institute of Technology's College of Engineering (Autonomous), \\ Kolhapur, Maharashtra, INDIA
}

*Corresponding Author: vaishnavi_10a@yahoo.co.in

Citation: Deshpande, V. V. and Thorvat, A. R. (2018). Experimental Investigation of Treatment of Domestic Wastewater Using Multi Soil Layering (MSL) System. Aquademia: Water, Environment and Technology, 2(2), 05. https://doi.org/10.20897/awet/3963

Published: November 28, 2018

\begin{abstract}
Soil has been used for the treatment of wastewater from long time ago. Domestic wastewater treatment and disposal is the serious problem our country is facing nowadays. If not treated it further pollutes the rivers. In villages or rural areas where centralized wastewater treatment is not possible because of the scattered houses, a decentralized treatment unit needs to be installed. Multi Soil Layering system is such a decentralized treatment used for the treatment of domestic wastewater. The main objective of this study is to investigate the experimental setup of Multi Soil layering system for the treatment of domestic wastewater. The pre-fabricated acrylic material model of dimension $50 \mathrm{~cm}(\mathrm{~L}) \times 20 \mathrm{~cm}(\mathrm{~W}) \times 60 \mathrm{~cm}(\mathrm{D})$ was used for the experimental analysis. The potential of the MSL for removal of pollutants from wastewater by changing the operating conditions like flow rate, aeration and non aeration condition was studied. The MSL system proved to be efficient for treatment of domestic wastewater. The study revealed that the flow rate of 0.2 $\mathrm{m}^{3} / \mathrm{m}^{2} /$ day with aeration condition was efficient for treating domestic wastewater by Multi Soil Layering System. For Flow rate of $0.2 \mathrm{~m}^{3} / \mathrm{m}^{2} /$ day, the average inlet and outlet ph was observed $\mathrm{pH} 6.75$ and 7.59 . The percent removal was as follows: BOD: $87.63 \%$, COD: $87.73 \%$, TSS: $77.12 \%$ and TP: $95.45 \%$.
\end{abstract}

Keywords: domestic wastewater, multi soil layering (MSL), soil mixture layer (SML), permeable layer (PL), hydraulic loading rate (HLR)

\section{INTRODUCTION}

Due to non-availability of full-fledged treatment facilities, large quantity of domestic wastewater is discharged into the environment without appropriate treatment and/or no treatment. Although the characteristics of wastewater from different communities vary significantly in quality and quantity, wastewater is able to be generalized as having high content of particulate matter, dissolved organic matter, nutrients and microbes. The receiving water bodies such as lakes, ponds, rivers etc may get heavily polluted, resulting in serious environmental and ecological problems; this issue is particularly severe in developing countries. Application of the MSL method to direct treatment of polluted river water was discussed in terms of its performance and adaptability to improve the public water environment (Masunaga et al., 2003). It is a challenge to provide reliable and affordable wastewater treatment facility to avoid serious environmental and ecological problems in such areas. It is really important to investigate the technological solution with some advantages such as low cost, easy for operation and maintenance and local materials usage which are easily available for the treatment of domestic wastewater. Exponential equation 
was used to express the experimental data to quantify the HLR (Hydraulic Loading Rate) influence on MSL treatment efficiency for $\mathrm{BOD}_{5}$ (Biochemical Oxygen Demand) parameter. (Khaoula et al., 2017).

Soil has been used for the treatment of wastewater from the long time ago. It was considered as a low cost decentralized wastewater treatment in rural areas in developing countries. It is naturally available and so it has been used in various natural treatment systems, septic tanks, soil trench system, soil filter beds etc. the main problem observed using soil as the natural filter media was clogging.

Some modifications were made to the existing treatment unit to overcome the problem of clogging, which reduces the clogging and increases the treatment efficiency. Hence the MSL system was introduced. The MSL system uses naturally available materials to reduce the cost of treatment.

As MSL systems are mainly composed of local materials such as soil, charcoal, sawdust and iron, the cost of construction is comparatively low. To construct an MSL system with a municipal wastewater treatment capacity of $100 \mathrm{~m}^{3} /$ day at an HLR of $1000 \mathrm{~L} / \mathrm{m}^{2} /$ day, the area required is around $100 \mathrm{~m}^{2}$, with a depth of $1 \mathrm{~m}$. If we assume that half of the system is composed of zeolite $\left(100 \mathrm{~m}^{3}\right)$, around 60 tonnes of zeolite would be required at a price of US $\$ 25 /$ tonne, at a total price of US $\$ 1500$ in China. The normal bulk density of SMB is around $1.2 \mathrm{~g} / \mathrm{cm}^{3}$ with sandy soil (Entisol) as the main material. The weight of SMB is around 120 tonnes, out of which $70 \%$ is soil (around 84 tonnes). Charcoal, iron and sawdust comprise the other $30 \%$ of SMB. The price for charcoal is around US $\$ 60 /$ tonne, sawdust US $\$ 25 /$ tonne and iron US $\$ 250 /$ tonne in China. Therefore, the whole cost for constructing such an MSL system can be less than US $\$ 10,000$ in China. The operation of the MSL system is easy, requires little maintenance and consumes little energy. In addition, most of the sludge can be decomposed inside the system. (Chen et al., 2009)

In the present study, for the area $0.1 \mathrm{~m}^{2}$ and depth $0.6 \mathrm{~m}$, half of the system is comprised of permeable material i.e. gravels where $45 \mathrm{~kg}$ of gravels are used. Price of the gravel is Rs $8 / \mathrm{kg}$ in India. $70 \%$ of Soil Mixture Layer (SML) is covered with soil. Around $18 \mathrm{~kg}$ of soil is used in the study. $30 \%$ of SML is covered with activated carbon, sawdust \& Iron scrap. The price of activated carbon is around Rs $1000 / \mathrm{kg}$; sawdust Rs $20 / \mathrm{kg}$ and iron scrap Rs $20 / \mathrm{kg}$ in India.

When compared with conventional soil treatment systems, this system could withstand a higher HLR and is less prone to clogging. The MSL system primarily consists of soil mixture layers (SMLs) and permeable layers (PLs). They are arranged in brick like pattern. The composition of the SML is approximately $70 \%$ to $80 \%$ soil and $20 \%$ to 30\% additional materials such as carbon powder, organic matter, and iron (Ho and Wang, 2015). The PL comprises aggregates of gravel, pumice, or zeolite approximately $3-5 \mathrm{~mm}$ in diameter. Removal of pollutants from wastewater through MSL is a complicated process involving various chemical, physical and biological processes. As a promising treatment technology and a cost-effective solution for sustainable water management, the need exists to develop increasingly deeper insight into the performance aspects of MSL systems (An et al., 2016). The combination of the MSL system with a sand filter has been found to be useful to efficiently reduce bacterial indicators and helminthes eggs (Latrach et al., 2016).The MSL system was effective for $\mathrm{BOD}_{5}$, and TP (Total Phosphorus) removals even at the ninth and the tenth years of operation. (Luanmanee et al., 2001). The MSL system can be operated and maintained at a low cost, requires small land area, and is ideal for urban areas in developing countries. Hence it is worthwhile to study the MSL system as an economical and feasible treatment facility and method for the removal of pollutants from domestic wastewater. Wastewater levels of contamination and HLRs are the major factors that influence the treatment efficiency of the MSL system and also of other wastewater treatment systems. (Masunaga et al., 2007).

The objective is to obtain more qualitative and quantitative data on the removal of pollutants from domestic wastewater under various conditions in MSLs. The purpose of this study was to investigate potential of the MSL system comprised of locally available materials in remediating pollution of domestic waste water by changing the operating parameters such as Hydraulic Loading Rate (HLR), Organic Loading Rate (OLR), Aeration and non Aeration methods and observing the performance of the MSL system.

\section{STUDY AREA AND EXPERIMENTAL SETUP}

In Kolhapur city the water supply is 135Million Litres per Day (MLD) and sewage generation is $80 \mathrm{MLD}$. The experimental setup of MSL was to be analyzed for the removal efficiency of domestic wastewater. The study area selected was the nallah carrying domestic wastewater in pratibhanagar area, Kolhapur, Maharashtra, India at $16^{\circ}$ $41.04773^{\prime} \mathrm{N}$ and $74^{\circ} 14.43258^{\prime} \mathrm{E}$. The nallah carries domestic wastewater from the nearby locality and is the sub source of jayanti nallah which is one of the major nallah in the city.

The mode of operation of MSL is based on the percolation infiltration using the ground as a purification system. The adsorption, infiltration and biodegradation are the major processes occurring in the filter (Lamzouri et al., 2016). The lab scale model is made up of pre fabricated acrylic material of dimension $50(\mathrm{~L}) \times 20(\mathrm{~W}) \times 60(\mathrm{D}) \mathrm{cm}$. The soil mixture layers of dimensions 12 × 20 × $5 \mathrm{~cm}$ were stacked in alternate pattern in the acrylic box separated 

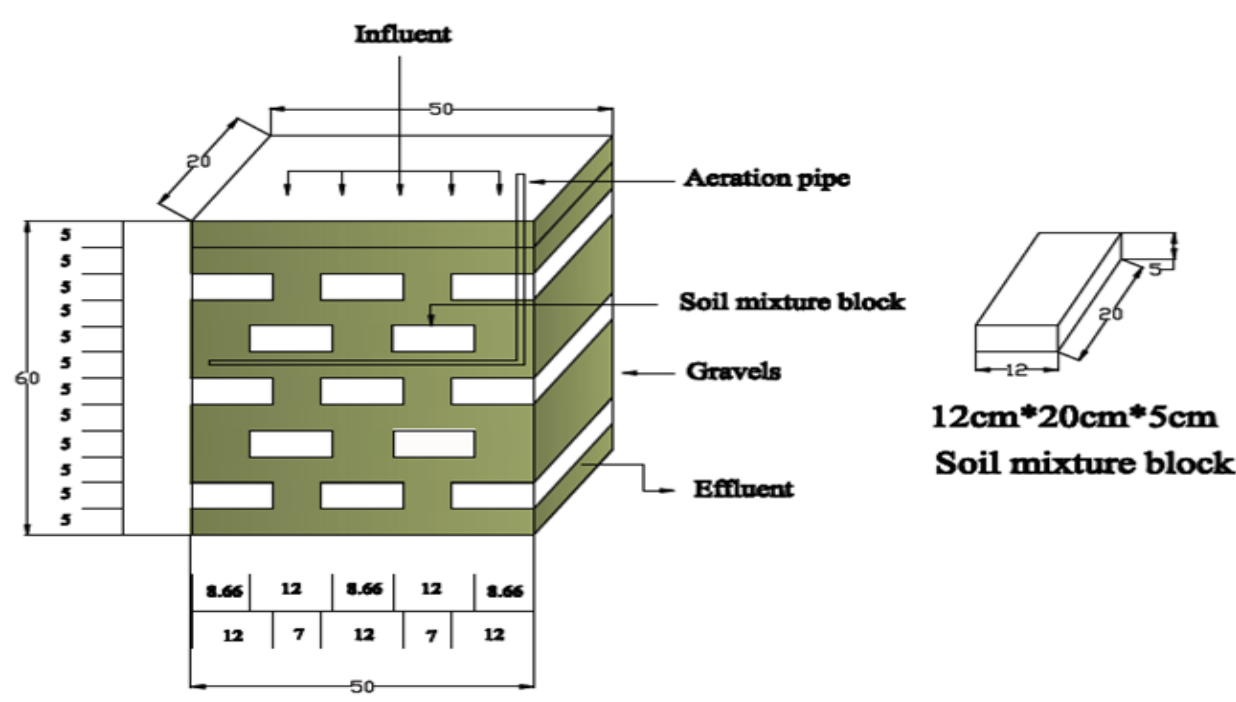

Soil mixture block

\section{$50 \mathrm{~cm} * 20 \mathrm{~cm} * 60 \mathrm{~cm}$ \\ Experimental Setup}

Figure 1. Structure of the Multi Soil Layering System

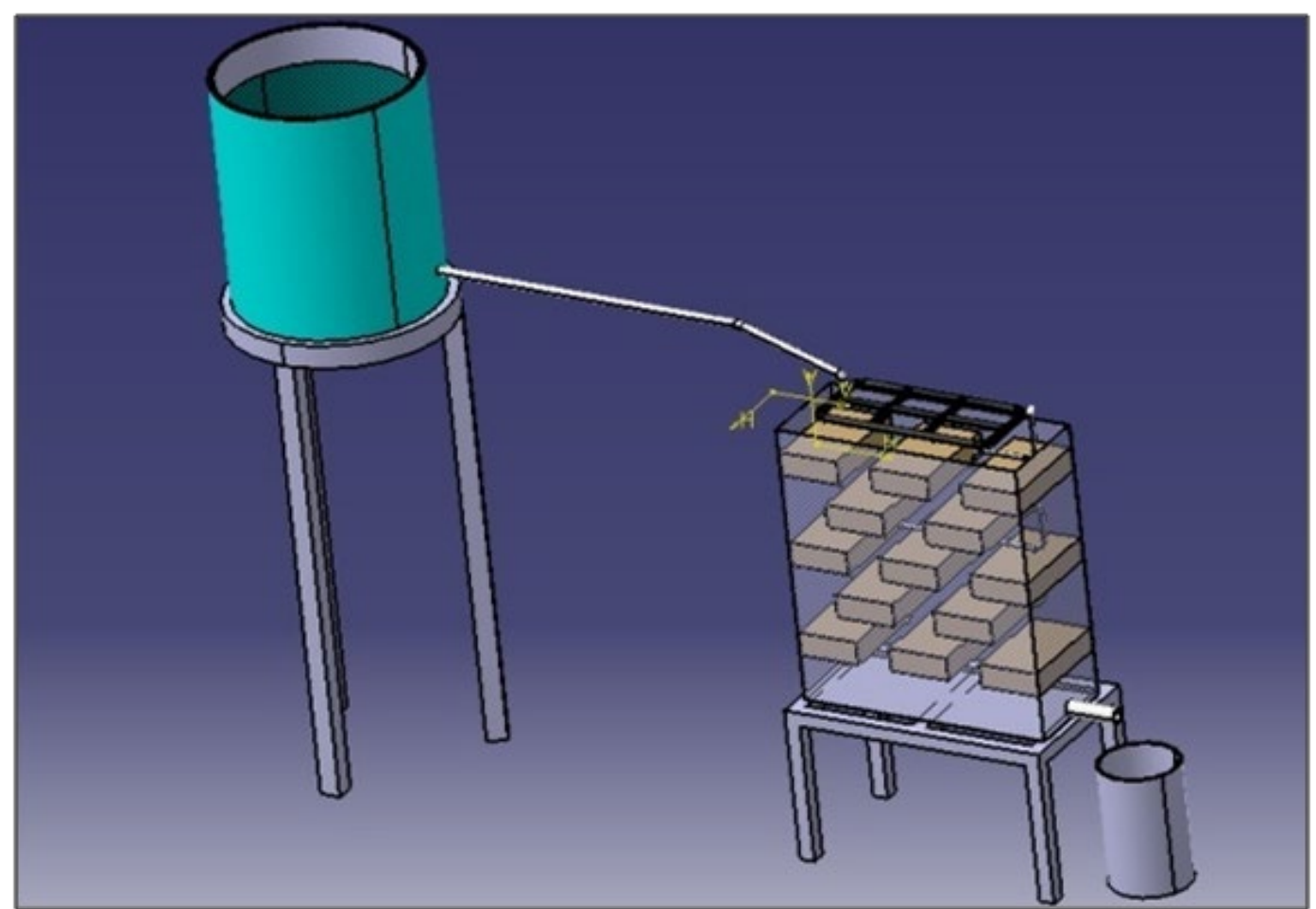

Figure 2. Schematic of the Experimental Setup

by permeable layer (Gravel) of length $5 \mathrm{~cm}$. The aerator used was of capacity $5 \mathrm{~m}^{3} / \mathrm{min}$. the aeration pipe was installed in between the $2^{\text {nd }}$ and $3^{\text {rd }}$ layer of SML in the permeable material.

Figure 1 indicates the structure of the MSL system.

The inlet distribution tank of 50 liters capacity was kept at the height above the experimental setup to enable flow of wastewater to the model by gravity. The adjusting valve was fitted to it to change the flow of incoming wastewater to the model as desired. The inlet pipe arrangement was made such as to allow uniform wastewater distribution throughout the model. The valve was connected to the outlet to allow the treated MSL water out of the system. The experimental analysis was carried out on twice a week basis for around 4 months for parameters pH, BOD (Biochemical Oxygen Demand), COD (Chemical Oxygen Demand), TSS (Total Suspended Solids) and TP (Total Phosphorus).

Figure 2 indicates the schematic of the experimental setup. 


\section{MATERIALS \& METHODOLOGY}

The materials used were mainly grouped as Soil mixture layers and Permeable layers. The materials used in MSL system are natural materials which are locally available. The materials used are:

\section{Soil Mixture Layers (SML)}

The discussions of material properties used in the experiments are as follows,

a. Soil: Soil is a mixture of organic matter, minerals, gases, liquids, and organisms that together support life. Soil is used to influence the microbial activity in treatment wastewater process. The laterite soil was used in this study. The soil passing through the sieve $4.75 \mathrm{~mm}$ was used in the soil mixture block.

b. Powdered activated carbon: Also known as activated charcoal, it is a form of carbon processed to have small, low-volume pores that increase the surface area available for adsorption and chemical reactions. Normally, activated carbons are made in particulate form as powders with large surface to volume ratio and particle sizes of less than $0.075 \mathrm{~mm}$.

c. Sawdust. Organic matter provides the carbon source for microorganisms. The sawdust passing through $4.75 \mathrm{~mm}$ sieve and retaining on $0.18 \mathrm{~mm}$ sieve was used in the experimental setup.

d. Iron scraps: Adding iron scraps into the SMLs facilitates phosphorus adsorption considerably. The iron scrap passing through $4.75 \mathrm{~mm}$ sieve and retaining on $2 \mathrm{~mm}$ sieve was used in the soil mixture block.

These materials were mixed together in the ratio as soil: powdered activated carbon: sawdust: iron scraps; 7:1:1:1 and the mixture is packed into jute bags each of size $12 \times 20 \times 5 \mathrm{~cm}$. These bags are then stacked in the treatment system with each layer separated by the permeable layer material.

\section{Permeable Layers}

It includes the material which will act as the permeable media for the wastewater to be passed. This material should be used according to the local availability.Various permeable layers that can be used may include pebbles, cobblers, gravels, used granular activated carbon, zeolite, etc. The selection of permeable materials varies the efficiency of treatment. Zeolite was substituted with comparatively cheaper and more environmental friendly materials, such as expanded clay aggregates, oyster shells, and already-used granular activated carbon collected from water purification plants (Ho and Wang, 2015). Natural zeolite is not easily available in India, there was a need to replace the permeable layer material as the zeolite was costly wherever available.

The efficiency of Thai local materials such as perlite, zeolitized perlite, gravel, and charcoal for use as alternative water-permeable layer materials of the MSL system was investigated (Boonsook et al., 2003). In this study gravels of diameter 3-6 cm were used as permeable material.

The study area for the collection of domestic wastewater samples in Kolhapur city was identified and the preliminary laboratory analysis of raw domestic wastewater was carried out for the parameters such as, $\mathrm{pH}, \mathrm{BOD}$, COD, TP and TSS. The locally available soil to be used in MSL system for the treatment of domestic wastewater was finalized. The preliminary laboratory analysis was done to analyze the physico-chemical characteristics of soil sample to be used in MSL system.

Experimental setup for the MSL system was prepared using locally available materials such as, soil, activated carbon, saw dust, iron particles, gravels etc. Analysis was carried out for the MSL treated wastewater on twice in a week basis for the parameters such as, $\mathrm{pH}, \mathrm{BOD}, \mathrm{COD}$, TP and SS. The effects of hydraulic behavior and fluctuations in wastewater contamination levels on the removal efficiency of the MSL system were demonstrated. And the performance of the MSL system under aeration and non aeration conditions were checked.

The pollution concentration of the raw domestic wastewater and the pollution concentration of the water samples treated and collected from the MSL were measured. The two sets of measurements were compared for determining the pollution removal efficiency of the MSL system.

\section{RESULTS AND DISCUSSION}

The soil used in this study was laterite soil, which is also known as 'Tambad' in local language. Table 1 shows the properties of the soil used in the study. The percentage of various sizes of particles in given dry soil sample is found by a particle size analysis or mechanical analysis. Particle size analysis or mechanical analysis is the separation of soil into its different soil fractions. Figure 3 shows the Logarithmic graph of Sieve analysis of soil used in the study. The results of mechanical analysis are plotted to get a particle size distribution curve. This curve gives idea about type and gradation of soil. The curve of the soil shows that the soil is well graded soil i.e. it has good representation of particles of all sizes. The initial parameters of domestic wastewater from the nallah are as listed in Table 2. It is observed that it is medium to high strength domestic wastewater. 
Table 1. Properties of the Soil Used in the Study

\begin{tabular}{lll}
\hline Parameter & Unit & Value \\
\hline $\mathrm{pH}$ & - & 6.80 \\
\hline Conductivity of the soil & $\mathrm{mS} / \mathrm{cm}$ & 0.28 \\
\hline Organic carbon & $\%$ & 0.62 \\
\hline phosphorus & $\mathrm{Kg} / \mathrm{ha}$ & 72.44 \\
\hline potash & $\mathrm{Kg} / \mathrm{ha}$ & 495.43 \\
\hline
\end{tabular}

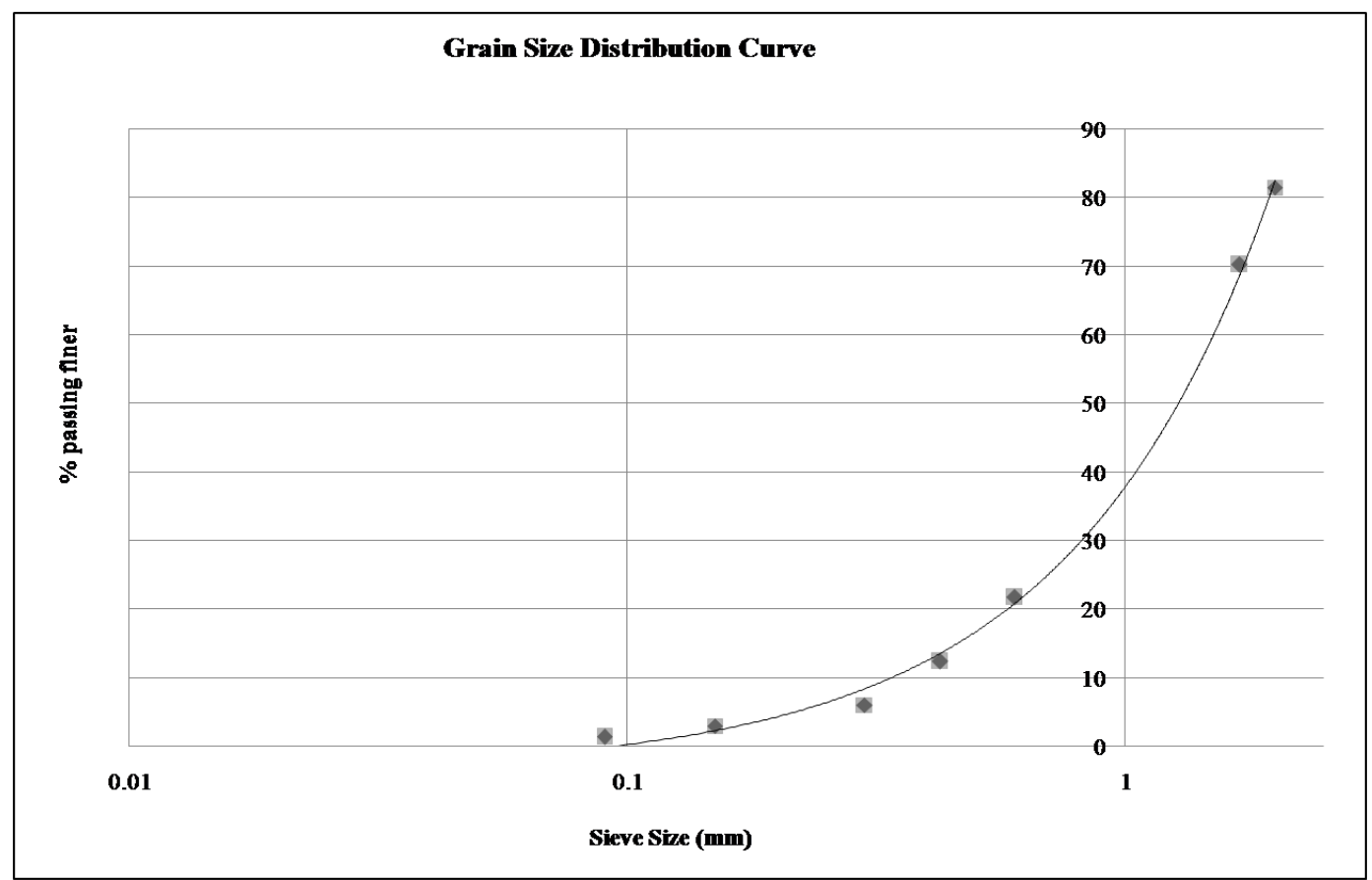

Figure 3. Logarithmic Graph of Sieve Analysis of Soil Used in the Study

Table 2. Initial Domestic Wastewater Analysis

\begin{tabular}{lcc}
\hline Parameter & Value & Unit \\
\hline pH & 6.82 & -- \\
\hline TSS & 480 & $\mathrm{mg} / \mathrm{l}$ \\
\hline TP & 12.48 & $\mathrm{mg} / \mathrm{l}$ \\
\hline BOD & 106 & $\mathrm{mg} / \mathrm{l}$ \\
\hline COD & 260 & $\mathrm{mg} / \mathrm{l}$ \\
\hline
\end{tabular}

\section{Results of Experimental Analysis by Changing the Operating Conditions}

The experimental analysis was carried out in 6 sets with different operating conditions. Set 1 consisted of Non Aeration condition with flow rate $0.2 \mathrm{~m}^{3} / \mathrm{m}^{2} /$ day, Set 2 consisted of Aeration condition with flow rate 0.2 $\mathrm{m}^{3} / \mathrm{m}^{2} /$ day, Set 3 consisted of Non Aeration condition with flow rate $0.3 \mathrm{~m}^{3} / \mathrm{m}^{2} /$ day, Set 4 consisted of Aeration condition with flow rate $0.3 \mathrm{~m}^{3} / \mathrm{m}^{2} /$ day, Set 5 consisted of Non Aeration condition with flow rate $0.4 \mathrm{~m}^{3} / \mathrm{m}^{2} /$ day, Set 6 consisted of Aeration condition with flow rate $0.4 \mathrm{~m}^{3} / \mathrm{m}^{2} /$ day.

Table 3 shows the average concentrations of inlet and outlet of different sets and their average removal efficiencies for the parameters $\mathrm{pH}, \mathrm{BOD}, \mathrm{COD}$, TSS and TP.

\section{Percentage Increase in $\mathrm{pH}$ and Removal Efficiencies of BOD, COD, TSS and TP}

The graphs plotted to show the removal efficiencies of BOD, COD, TSS and TP in different sets are shown in Figures 4, 5, 6 and 7.

Wastewater Quality at the Inlet and Outlet were studied to calculate the Removal Efficiencies of Different Sets by considering the parameters: a. $p H, b . B O D, c . C O D, d$. TSS, e. TP

a. $p H: \mathrm{pH}$ refers to the measurement of hydrogen ion activity in the solution. The influent $\mathrm{pH}$ ranged from 6.8 to 7.02 and the effluent $\mathrm{pH}$ ranged from 7.1 to 7.8 . The $\mathrm{pH}$ of the wastewater changes from acidic to basic, and increases upto 11-13\%. The flow rate change and aeration-non aeration condition does not majorly affect the $\mathrm{pH}$ of the treated water. One of the reasons for the increase in $\mathrm{pH}$ is due to the algal growth in the model. 
Table 3. Wastewater Quality at the Inlet and Outlet and Removal Efficiencies of Different Sets

\begin{tabular}{|c|c|c|c|c|c|c|c|}
\hline $\begin{array}{l}\text { Flow } \\
\text { Rate } \\
\end{array}$ & Test Condition & & $\mathrm{pH}$ & $\begin{array}{c}\text { BOD } \\
(\mathrm{mg} / \mathrm{l})\end{array}$ & $\begin{array}{c}\text { COD } \\
(\mathrm{mg} / \mathrm{l})\end{array}$ & $\begin{array}{c}\text { TSS } \\
(\mathrm{mg} / \mathrm{l})\end{array}$ & $\begin{array}{c}\mathrm{TP} \\
(\mathrm{mg} / \mathrm{l}) \\
\end{array}$ \\
\hline & & Inlet & 6.76 & 166.4 & 378.65 & 785.71 & 16.62 \\
\hline \multirow[t]{3}{*}{ Set 1} & Non Aeration & Outlet & 7.54 & 28.65 & 64.52 & 191.42 & 1.02 \\
\hline & & \%removal & - & 82.44 & 81.52 & 75.68 & 94.26 \\
\hline & & In & 6.75 & 203.35 & 418.57 & 842.85 & 14.14 \\
\hline \multirow[t]{3}{*}{ Set 2} & Aeration & Out & 7.59 & 24.62 & 48.73 & 194.28 & 0.71 \\
\hline & & \%removal & - & 87.63 & 87.73 & 77.12 & 95.45 \\
\hline & & Inlet & 6.64 & 138.47 & 320.85 & 734.28 & 16.78 \\
\hline \multirow[t]{3}{*}{ Set 3} & Non Aeration & Outlet & 7.48 & 34.85 & 74.28 & 205.71 & 2.54 \\
\hline & & \%removal & - & 74.78 & 76.91 & 71.74 & 83.94 \\
\hline & & Inlet & 6.77 & 174.05 & 336 & 720 & 16.9 \\
\hline \multirow[t]{3}{*}{ Set 4} & Aeration & Outlet & 7.61 & 41.225 & 67.71 & 197.40 & 1.98 \\
\hline & & \%removal & - & 75.88 & 79.01 & 72.29 & 88 \\
\hline & & Inlet & 6.64 & 150.9 & 318.85 & 717.14 & 15.04 \\
\hline \multirow[t]{3}{*}{ Set 5} & Non Aeration & Outlet & 7.46 & 42.32 & 85.88 & 220 & 3.05 \\
\hline & & \%removal & - & 68.67 & 71.42 & 69.11 & 79.49 \\
\hline & & Inlet & 6.54 & 184 & 355.88 & 725.71 & 14.03 \\
\hline \multirow[t]{2}{*}{ Set 6} & Aeration & Outlet & 7.34 & 51.11 & 91.55 & 217.14 & 3.824 \\
\hline & & \%removal & - & 71.35 & 72.52 & 70.08 & 79.75 \\
\hline
\end{tabular}

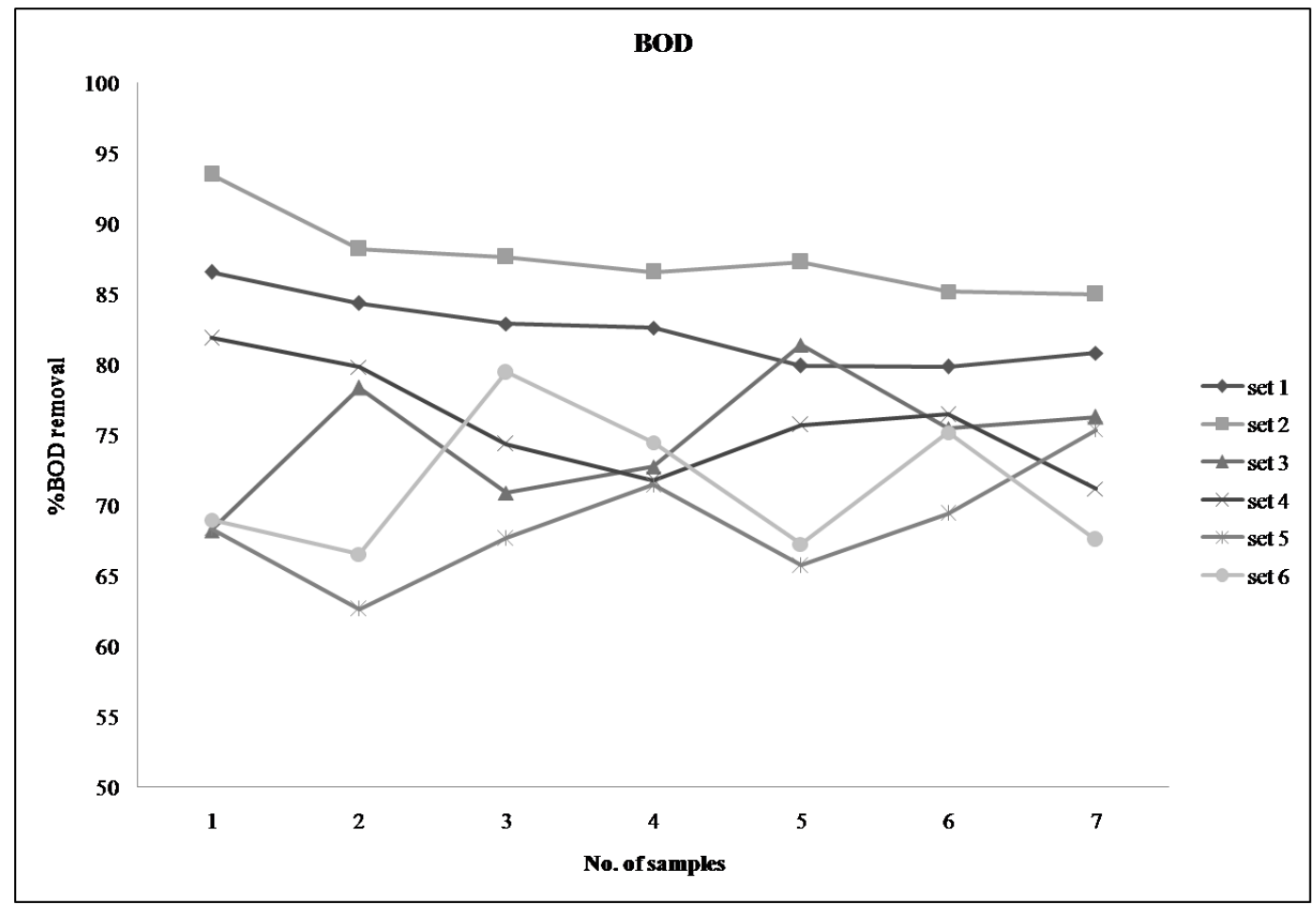

Figure 4. Removal Efficiency of Biological Oxygen Demand

b. Biological Oxygen Demand (BOD): Figure 4 shows the trend line of percentage removal of BOD for the no. of sampling for different sets. The soil enables various microorganisms to grow in it and so it is the main carrier of the microorganisms in the system.

The removal efficiency of BOD for set 1: $82.44 \%$, for set 2: $87.63 \%$, for set 3: $74.78 \%$, for set $4: 7: 5.88 \%$, for set 568.67 and for set $6: 71.35 \%$.

The BOD removal efficiency for set 2 was highest and was $87.963 \%$. For set 2 , the average inlet BOD value observed was $203.35 \mathrm{mg} / 1$ and the average outlet BOD value observed was $24.62 \mathrm{mg} / \mathrm{l}$.

It was observed that as the flow rate increased the removal efficiency of the BOD decreased. Provided the intermittent aeration, the efficiency was increased as aeration condition enabled the decomposition of microorganisms at a higher rate.

c. Chemical Oxygen Demand (COD): Figure 5 shows the trend line of percentage removal of COD for the no. of sampling for different sets.

The removal efficiency of COD for set $1: 81.52 \%$, for set $2: 87.73 \%$, for set $3: 76.91 \%$, for set $4: 79.01 \%$, for set $5: 71.42 \%$ and for set $6: 72.52 \%$. 


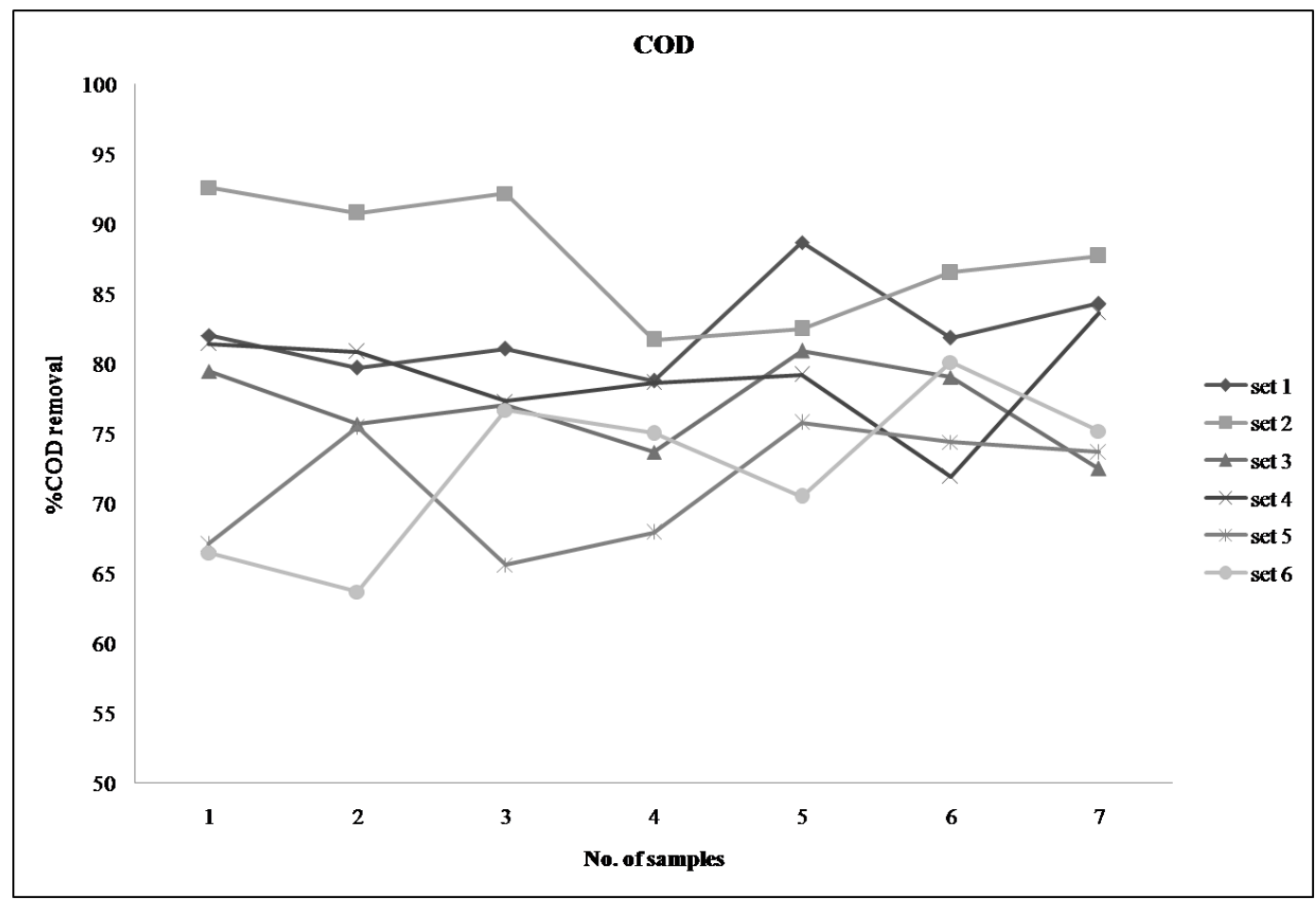

Figure 5. Removal Efficiency of Chemical Oxygen Demand

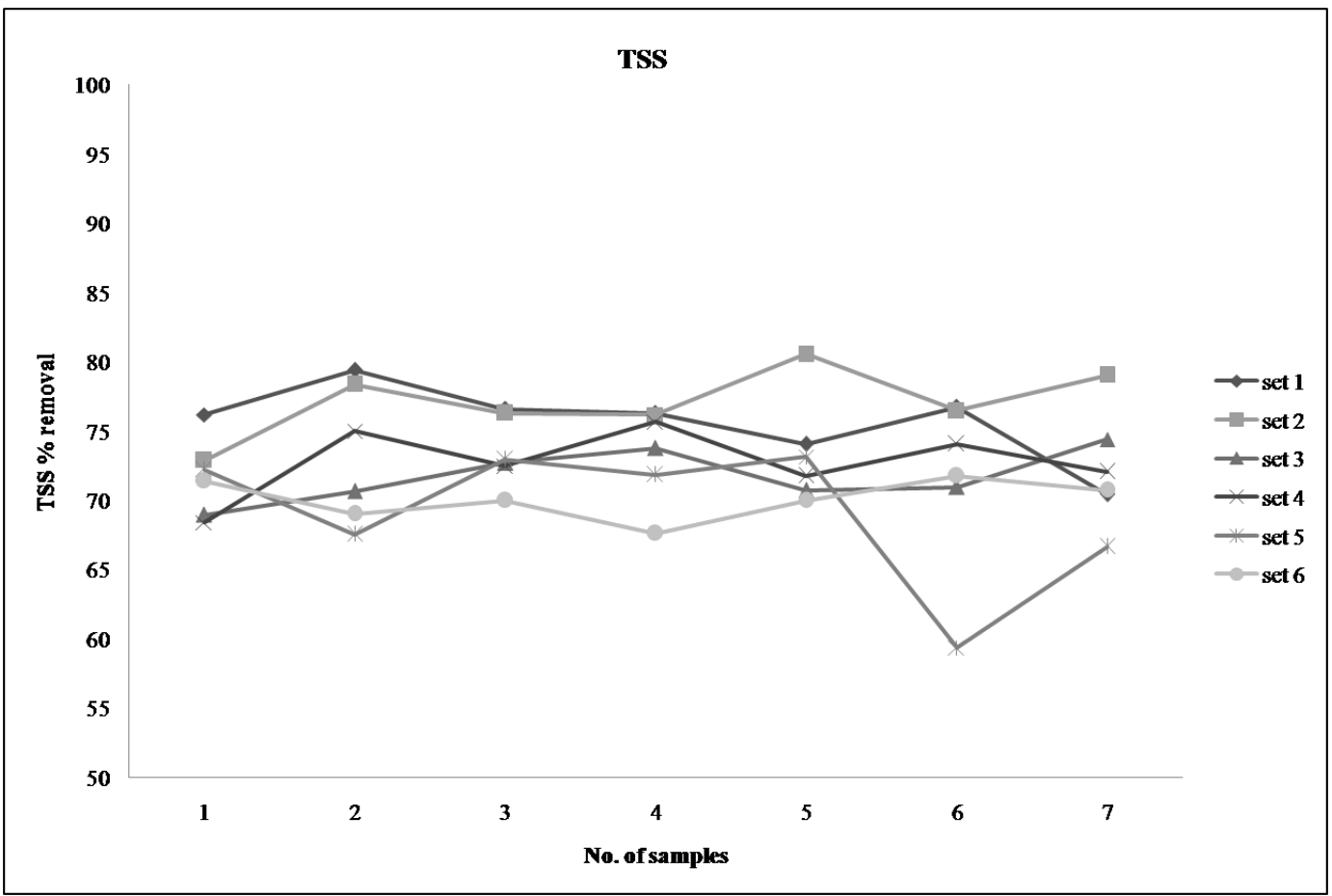

Figure 6. Removal Efficiency of Total Suspended Solids

The COD removal efficiency for set 2 was highest and was $87.73 \%$. For set 2 , the average inlet COD value observed was $418.57 \mathrm{mg} / \mathrm{l}$ and the average outlet BOD value observed was $48.73 \mathrm{mg} / \mathrm{l}$.

The COD removal efficiency of the MSL was good with a lower HLR and decreased as the HLR was increased. The aeration condition improved the efficiency of the COD. The intermittent aeration enhanced the removal efficiency of COD.

d. Total suspended solids (TSS): Figure 6 shows the trend line of percentage removal of TSS for the no. of sampling for different sets Due to the physical interlocking of solids between the pores in the gravels and soil mixture blocks; the TSS removal efficiency of the MSL is high.

The removal efficiency of TSS for set 1: $75.68 \%$, for set $2: 77.12 \%$, for set $3: 71.74 \%$, for set $4: 72.29 \%$, for set 5: $69.11 \%$ and for set $6: 70.08 \%$. 


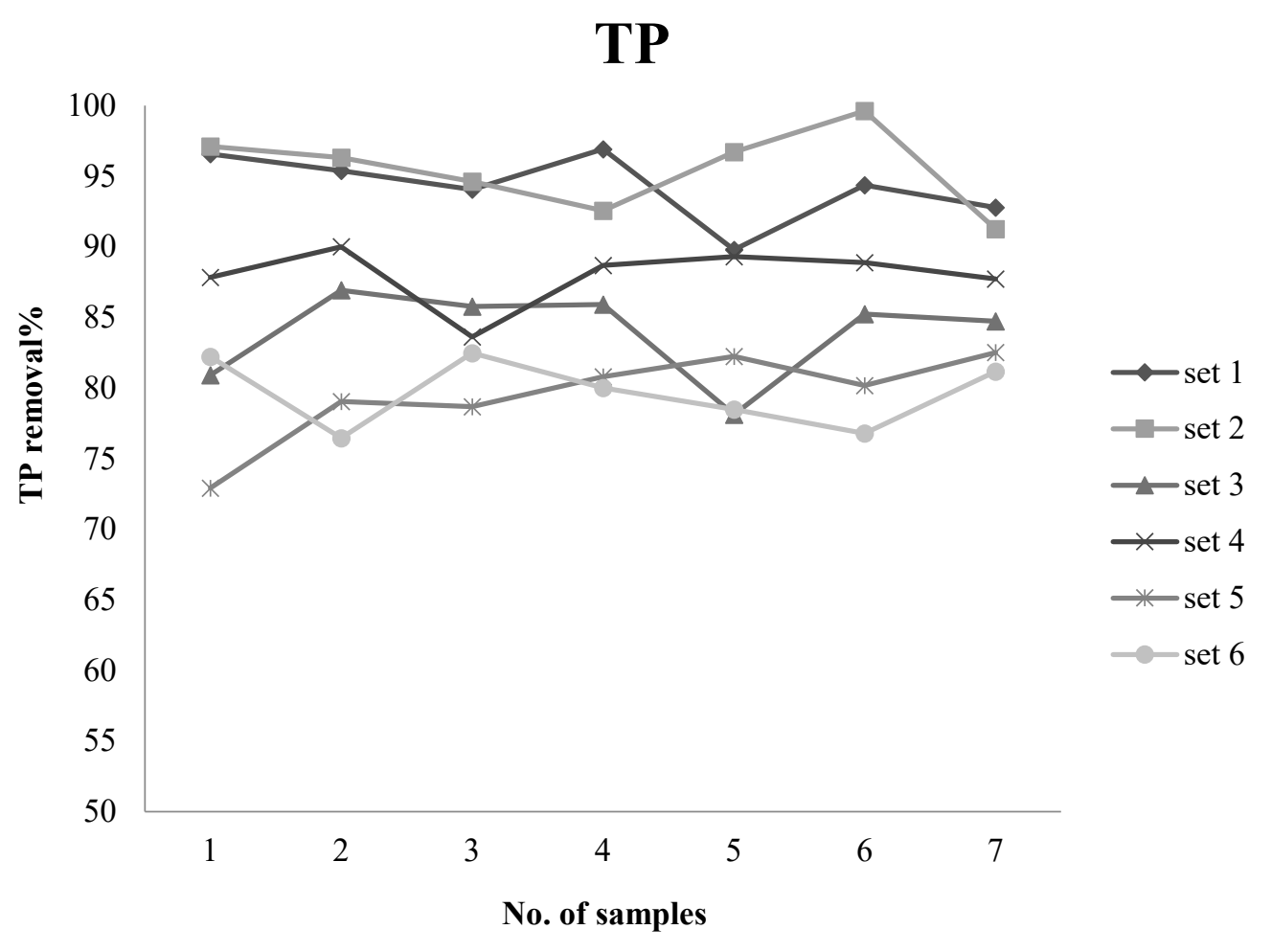

Figure 7. Removal Efficiency of Total Phosphorus

The TSS removal efficiency for set 2 was highest and was $77.12 \%$. For set 2 , the average inlet TSS value observed was $842.85 \mathrm{mg} / \mathrm{l}$ and the average outlet TSS value observed was $194.28 \mathrm{mg} / \mathrm{l}$.

As the flow rate increases TSS removal efficiency gradually decreases. By providing intermittent aeration, the solids are decomposed at a faster rate, which enables the efficiency of TSS removal increase. It was observed that the TSS of the raw domestic wastewater was high because there was the dumping of solid waste in the nallah by the residents living nearby nallah.

e. Total phosphorus (TP): Figure 7 shows the trend line of percentage removal of TP for the no. of sampling for different sets.

The removal efficiency of TP for set 1: $94.26 \%$, for set $2: 95.45 \%$, for set $3: 83.94 \%$, for set $4: 88 \%$, for set 5: $79.49 \%$ and for set $6: 79.75 \%$.

The TP removal efficiency for set 2 was highest and was $95.45 \%$. For set 2 , the average inlet TP value observed was $14.14 \mathrm{mg} / \mathrm{l}$ and the average outlet TP value observed was $0.71 \mathrm{mg} / \mathrm{l}$.

It was observed that MSL system is very efficient for the removal of phosphorus from the domestic wastewater. The phosphorus removal efficiency was higher at a lower flow rate and decreased gradually at a higher flow rate.

\section{CONCLUSIONS}

In the present study experimental set up was installed for MSL system and series of indoor tests were conducted. The MSL system proved to be efficient in remediating the pollution of domestic wastewater. The BOD removal efficiency was 68.67 to $87.63 \%$. The COD removal efficiency was 71.42 to $87.73 \%$. The TSS removal efficiency was 69.11 to $77.12 \%$. The TP removal efficiency was 79.49 to $95.45 \%$. The aeration and non aeration method was studied for the MSL system, the aeration system proved to be more efficient. The effects of varying hydraulic loading rates were studied for the removal efficiency by the MSL system. The change in hydraulic loading rate inside the experimental setup discovered that the performance of the MSL decreased with increasing loading rate. The flow rate of $0.2 \mathrm{~m}^{3} / \mathrm{m}^{2} /$ day with aeration condition was efficient for treating domestic wastewater by multi soil layering system. Once the capacity of purification of soil is over, the soil can be further used in agricultural land as fertile soil.

Clogging was not observed during the 4 months running period of the model, due to the time constraint. So there is a further scope of study related to clogging. Also there is a scope to study the efficiency of treatment by using different permutation combinations in the soil mixture layers (SML's) and permeable layers (PL) and the removal efficiency of the model by changing the capacity of aerator. 


\section{REFERENCES}

An, C. J., McBean, E., Huang, G. H., Yao, Y., Zhang, P., Chen, X. J. and Li, Y. P. (2016). Multi-Soil-Layering Systems for Wastewater Treatment in Small and Remote Communities. Journal of Environmental Informatics, 27(2), 131-144. https://doi.org/10.3808/jei.201500328

Boonsook, P., Luanmanee, S., Attanandana, T., Kamidouzono, A., Masunaga, T. and Wakatsuki, T. (2003). A Comparative Study of Permeable Layer Materials and Aeration Regime on Efficiency of Multi-Soil-Layering System for Domestic Wastewater Treatment in Thailand. Soil Science and Plant Nutrition, 49(6), 873-882. https:// doi.org/10.1080/00380768.2003.10410350

Chen, X., Luo, A. C., Sato, K., Wakatsuki, T. and Masunaga, T. (2009). An introduction of a multi-soil-layering system: a novel green technology for wastewater treatment in rural areas. Water and Environment Journal, 23, 255262. https://doi.org/10.1111/j.1747-6593.2008.00143.x

Ho, C. C. and Wang, P. H. (2015). Efficiency of a Multi-Soil-Layering System on Wastewater Treatment Using Environment-Friendly Filter Materials. International Journal of Environmental Research and Public Health, 12(3), 33623380. https://doi.org/10.3390/ijerph120303362

Khaoula, L., Mustapha, M., Tsugiyuki, M., Said, O., Houssine, B., Laila, M. (2017). Wastewater Treatment Plant Performance inside Multi-Soil-Layering System. American Journal of Applied Sciences, 14(1), 53-59. https://doi.org/10.3844/ajassp.2017.53.59

Lamzouri, K., Mahi, M., Ouatar, S., Bartali, E., Masunaga, T., Latrach, L. and Mandi, L. (2016). Application of Multi-soil-layering technique for wastewater treatment in Moroccan rural areas: study of the operation process for an engineering design. Journal of Materials and Environmental Science, 7(2), 579-585. ISSN: 2028-2508.

Latrach, L., Ouazzani, N., Masunaga, T., Hejjaj, A., Bouhoum, K., Mahi, M. and Mandi, L. (2016). Domestic wastewater disinfection by combined treatment using multi-soil-layering system and sand filters (MSL-SF): A laboratory pilot study. Ecological Engineering, 91, 294-301. https://doi.org/10.1016/j.ecoleng.2016.02.036

Luanmanee, S., Attanandana, T., Masunaga, T. and Wakatsuki, T. (2001). The efficiency of a multi-soil-layering system on domestic wastewater treatment during the ninth and tenth years of operation. Ecological Engineering, 18(2), 185-199. https://doi.org/10.1016/S0925-8574(01)00077-5

Masunaga, T., Sato, K., Mori, J., Shirahama, M., Kudo, H. and Wakatsuki, T. (2007). Characteristics of wastewater treatment using a multi-soil-layering system in relation to wastewater contamination levels and hydraulic loading rates. Soil Science \& Plant Nutrition, 53(2), 215-223. https://doi.org/10.1111/j.1747-0765.2007.00128.x

Masunaga, T., Sato, K., Zennami, T., Fujii, S. and Wakatsuki, T. (2003). Direct treatment of polluted river water by the multi-soil-layering method. Journal of Water and Environment Technology, 1(1), 97-104. https://doi.org/10.2965/jwet.2003.97 